\title{
トンネル覆エコンクリート検査に向けたレーザー打音検査用 小型高出力高繰り返しレーザー装置の開発
}

\author{
岡田大，長谷川 登，三上 勝大，近藤修司，錦野 将元，河内 哲哉 \\ (国) 量子科学技術研究開発機構 量子ビーム科学研究部門 関西光科学研究所 (

\section{Development of High-Power and High Repetition Rate Compact Pulse Laser System for Using the Laser Hammering Test of the Inspection of Tunnel Concrete}

\author{
Hajime OKADA, Noboru HASEGAWA, Katsuhiro MIKAMI, Shuji KONDO, \\ Masaharu NISHIKINO, and Tetsuya KAWACHI \\ National Institute for Quantum and Radiological Science and Technology (QST), 8-1-7 Umemidai, Kizugawa, Kyoto 619-0215
}

(Received April 1, 2012)

\begin{abstract}
We developed a flash lamp-pumped Nd:YAG laser with $2 \mathrm{~J}, 50 \mathrm{~Hz}$ for a laser-hammering method that inspects tunnel-lining concrete. A simple and compact laser system with a thermal lens effect was compensated by an adjustment of the image tube with high impact resistance and stability. As a result of a 1.5-month outdoor practical test, this laser system was shown to be available for maintenance-free operation.
\end{abstract}

Key Words: High-power pulse laser, Outdoor-use, Laser hammering test, Concrete maintenance

\section{1. はじめに}

急峻な地形を有する我が国にはトンネルや橋梁を始め とするコンクリートを使用した社会インフラが数多くあ るが，その多くに高経年化に起因する劣化が懸念されて いる．現在のコンクリート内部の検査方法の主流である 打音法では，検査員がハンマーでコンクリートを吒いた 際に発生する音の違いを耳で聞き分けることにより健全 性を診断している。信頼性が高く多くの実績があるが， 接触式であるため検査には時間がかかる事に加え, 検査 員に危険も伴う。日本のトンネルの総延長は鉄道・道路

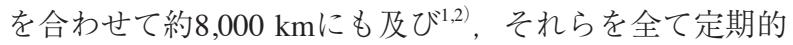
に点検するには膨大な時間とコストが掛かるため，高 速, 非接触, 遠隔操作が可能な新しい定量検査技術の 開発が盛んに行われている。我々はレーザー照射によ る打撃とレーザー振動計測による振動の検出を同時に 行うことにより従来の人の手による打音法と同様の検 査を遠隔で行うことが可能と期待される「レーザー欠陥 検出法 $\rfloor^{3-6)}$ の高速化にレーザー技術総合研究所と協力し て取り組んでいる ${ }^{7-9)}$.

\section{2.レーザーを利用したトンネル内部の遠隔検査}

「レーザー欠陥検出法」では，打音法における「打撃」 と「音の検知」を2つのレーザーを用いることで遠隔・非 接触で行う (Fig. 1).「振動励起レーザー（Hammering la- ser）」は打音検査におけるハンマーに相当し，遠隔でコ ンクリートに強い衝撃を与えることのできる高強度のパ ルスレーザーである。コンクリート表面を僅かにアブ レーションさせることで効率良くコンクリートを振動さ せることが可能である.コンクリートの内部に欠陥があ る場合には, 打音検査と同様に, その振動に変化が生じ る.「振動計測システム (Laser vibrometer)」は打音検査に おける耳に相当し，コンクリート表面の微細な振動を レーザー干渉計により，遠隔・非接触で検出する，振動 しているコンクリート表面から反射してくる信号光の周 波数変調(ドップラー効果)を参照光と干渉させることで 計測し，表面の振動を計測する ${ }^{3-5)}$ 。本手法は，西日本旅 客鉄道株式会社 · 公益財団法人鉄道総合技術研究所 - 公 益財団法人レーザー技術総合研究所による先行研究によ り，実際のトンネルの覆工コンクリート内部の欠陷検出 が打音検査と同様に可能であることが示されている ${ }^{6)}$. 「レーザー打音法 (Laser Hammering Test: LHT)」とも呼ば れる本手法は, レーザー干渉計により計測する振動周波 数領域が人間の可聴域と重複しているため, 従来の打音 法と高い互換性が期待でき，その高速化が望まれてい る.レーザー打音検査の検査速度は, Fig. 1 中の太線枠 で示した「振動励起レーザー」,「走査装置(Scan system)」, 「振動計測システム」の動作速度によって決定さ れる。本稿では特に量子科学技術研究開発機構が開発を 担当している高繰り返し動作が可能な振動励起レーザー について述べる。 


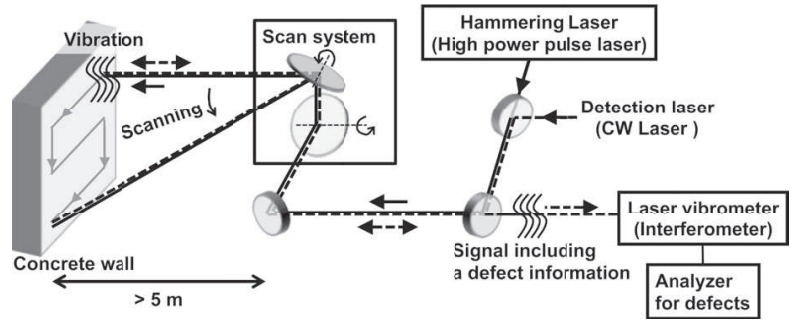

Fig. 1 Schematic of laser hammering test.

3. レーザー打音検査用小型高出力高繰り返し レーザー装置の開発

3.1 レーザー打音検査の高速化に必要な振動励起 レーザーの性能

振動励起レーザーの能力は，レーザー打音検査におい て, コンクリートを加振する能力, 検査速度, 検査精度 等に影響を与える. Table 1にレーザー打音検査の高速化 に必要な振動励起レーザーの性能及び今回開発したレー ザーの性能を示す。更に屋外での使用を前提とするた め, 装置の小型化や屋外に招ける動作安定性なども必要 となる. 振動励起レーザーによって, 深さ数 $\mathrm{cm}$ に位置 する欠陥を検出するには，1 J以上のパルス出力エネル ギー, $100 \mathrm{~ns}$ 以下のパルス幅, $5 \mathrm{~m}$ 以上離れた位置にお いて直径5-10 mm程度にビームを絞る集光性能が求めら れる れ, $^{6,}$ ，集光強度が高すぎるとコンクリート面を破壊 してしまうため照射強度を sub-GW/ $\mathrm{cm}^{2}$ 程度に抑えつつ, 大きなエネルギーを投入する必要がある，検査速度を決 定するレーザーの繰り返し数については, 最大で $100 \mathrm{~Hz}$ 程度が適切となる。これは，レーザー打音検査では，可 聴域の振動(具体的には $100 \mathrm{~Hz}-20 \mathrm{kHz}$ ) を計測対象とし ているためである.

Fig. 2 に，レーザーメーカからカタログ品として販売 されているフラッシュランプ励起レーザーのパルス繰り 返し数とパルス出力エネルギーを示す. Fig. 2 中の点線 は平均出力 $100 \mathrm{~W}$ 示しており，これを越える製品はほ とんど存在しないことが分かる。レーザー打音計測を高 速化するには, 前述のようにパルスエネルギーと繰り返 し数のバランスが重要であり, Fig. 2 中の明るい領域の 性能が必要である，高出力レーザーを高い繰り返しで動

Table 1 Requirement and performance of the developed hammering laser.

\begin{tabular}{llll}
\hline & $\begin{array}{l}\text { Laser } \\
\text { parameter }\end{array}$ & Requirement & $\begin{array}{l}\text { Developed } \\
\text { performance }\end{array}$ \\
\hline & $\begin{array}{l}\text { Repetition } \\
\text { rate }\end{array}$ & $>1 \mathrm{~J} / \mathrm{shot}$ & $2 \mathrm{~J} / \mathrm{shot}$ \\
\cline { 2 - 4 } $\begin{array}{l}\text { Performance of } \\
\text { the vibration of } \\
\text { the concrete }\end{array}$ & Duration & $<100 \mathrm{~ns}$ & $10 \mathrm{~ns}$ \\
\cline { 2 - 4 } & Focusibility & $<10 \mathrm{~mm} \phi$ & $7 \mathrm{~mm} \times 10 \mathrm{~mm}$ \\
\hline $\begin{array}{l}\text { Inspection } \\
\text { speed }\end{array}$ & $\begin{array}{l}\text { Repetition } \\
\text { rate }\end{array}$ & $50-100 \mathrm{~Hz}$ & $50 \mathrm{~Hz}$ \\
\hline Outdoor use & $\begin{array}{l}\text { Footprint } \\
\text { size }\end{array}$ & $<2 \mathrm{~m} \times 1 \mathrm{~m}$ & $1.8 \mathrm{~m} \times 0.7 \mathrm{~m}$ \\
\hline
\end{tabular}

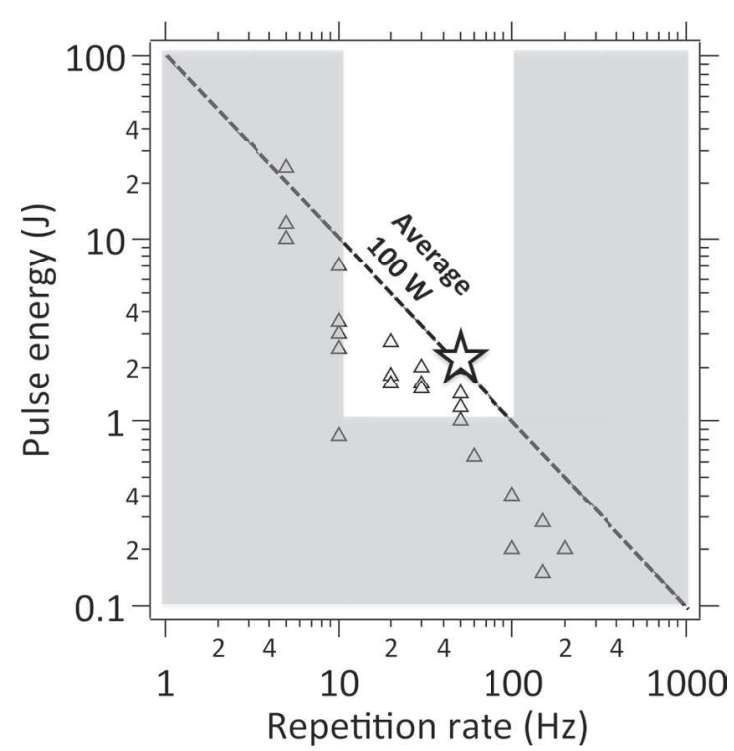

Fig. 2 Commercial catalog specs of the flash lamp pumped high average power laser. Bright area shows suitable lasers for a hammering laser. the star indicates the performance of the developed hammering laser.

作させる場合，レーザー媒質の励起に伴う熱により生じ る波面の歪み(熱レンズ効果等)の影響を低減する必要が ある。この影響を低減する手法としては, 波面を補正す る誘導ブリルアン散乱による位相共役鏡 $(\mathrm{SBS}-\mathrm{PCM})^{10)}$, 冷却効率を高めてレーザー媒質内の熱勾配を低減するク ライオスタットによる結晶の極低温冷却システム ${ }^{11}$ 等が 挙げられる。平均出力 $100 \mathrm{~W}$ を越えるレーザーでは, こ れらの手法が良く用いられるが, 屋外での運用を前提と する振動励起レーザーでは，SBS-PCMへの入射スペク トル線幅の安定性や結晶を極低温に維持する装置群が付 加される事により, 動作安定性の低下や装置の大型化が 懸念される。本研究では, 光学素子数を低減した単純な 光学レイアウト設計による小型化と平均出力 $100 \mathrm{~W}$ 両 立するレーザーの開発を目指した。

Fig. 3 に移動を伴う運用を考慮したレーザー打音検査 装置の概略を示す。装置本体は上部の振動励起レー ザー，下部のレーザー振動計測部，先端のスキャナー部 分から構成される (太線内). Fig. 3 中の矢印はレーザー の出射方向を示し，トンネルの円弧に沿って計測位置を 移動することを想定している。レーザー打音検査では, 微小なコンクリート振動を計測対象とするため, 振動励 起レーザー及び外部からの振動が振動計測部に伝わらな いように各部に防音・防振対策を施しており，現状では 装置が静止した状態で振動計測を行う。スキャナーによ りトンネル内壁の円周部に沿った検査が可能であるが, トンネル内での移動を伴う運用のために, レーザーの電 源, 冷却装置等も含めた装置全体がトンネル内に導入可 能な車両に搭載可能であることが求められる (STOP \& $\mathrm{GO}$ による計測)。例えば, 一般的な車両の荷台 $(4 \mathrm{t}$ 卜 ラック： $6.2 \mathrm{~m} \times 2.1 \mathrm{~m}$ ) に搭載し計測を行うためには, 装置本体の寸法はその $1 / 4$ 程度の長さ $3 \mathrm{~m}$, 幅 $1 \mathrm{~m}$ 以下で あることが望ましい，筐体内での防振・耐衝撃性能，ス 


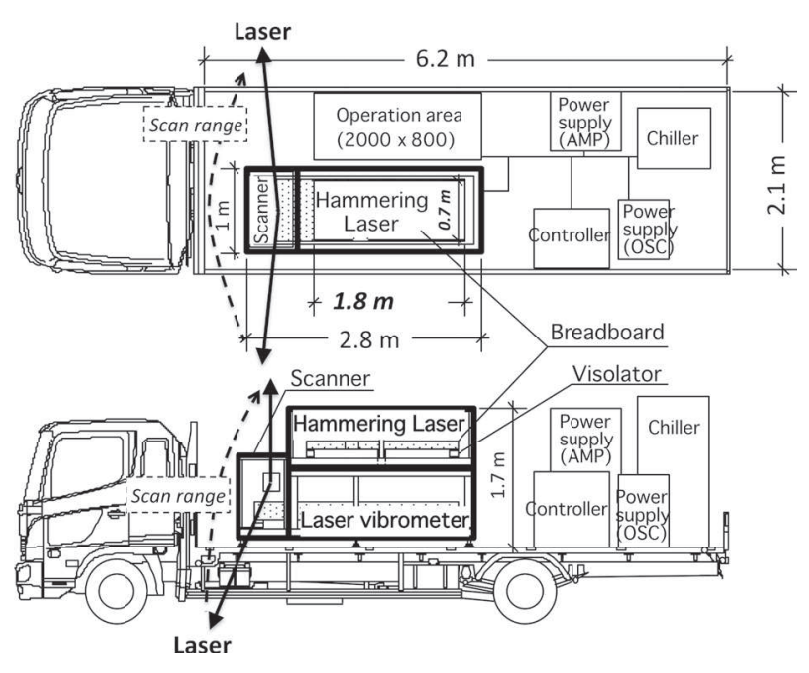

Fig. 3 Laser hammering test system on a vehicle.

キャナー部分の大きさを考慮すると振動励起レーザー は, 長さ $2 \mathrm{~m}$ 以下, 幅 $0.7 \mathrm{~m}$ 以下の光学定盤上に収める必 要がある。

\section{2 光学素子の固定手法に関する耐衝撃性の検討}

レーザー打音装置は，検査対象であるトンネルまでの 長距離輸送や, STOP \& GOによる計測の際に低速では あるが移動することが想定される。レーザーシステムを 構成する光学素子は, 周辺環境からの振動等の小さい力 に加えて, 衝突による衝撃等の大きな力に晒される可能 性があり，耐衝撃性も重要課題となる。Fig.4(a)，（b) に, レーザー内蔵のポジションセンサ(駿河精機製C400C016S/K55) を使用した耐衝撃試験の配置とその試験方 法を示す. ポジションセンサや光学素子は寸法 $0.6 \mathrm{~m} \times$ $0.3 \mathrm{~m}$ のブレッドボードに設置し, ボードの長手方向を 床から0.1 m持ち上げてそのまま自由落下させ，衝撃前 後のレーザーポインティングの角度ずれを測定した。こ れは時速 $5 \mathrm{~km}$ での移動速度における衝突に相当する。

Fig. 4(c)に，ミラーホルダーをポストスタンド方式とペ デスタル方式で定盤に固定した場合の結果をそれぞれ示 す. 衝撃後の角度ずれは, 両方式とも測定下限の $0.001^{\circ}$ 程度であり，低速移動時の衝撃に対しては十分な固定強 度が得られている事が分かった。本結果を受けて, 光学 部品の上下方向の調整が必要な部品 (レンズ等)に関して はポストスタンド，その他ではペデスタルによる固定方 式を採用した。しかしながら, 現状の評価方法では, 光
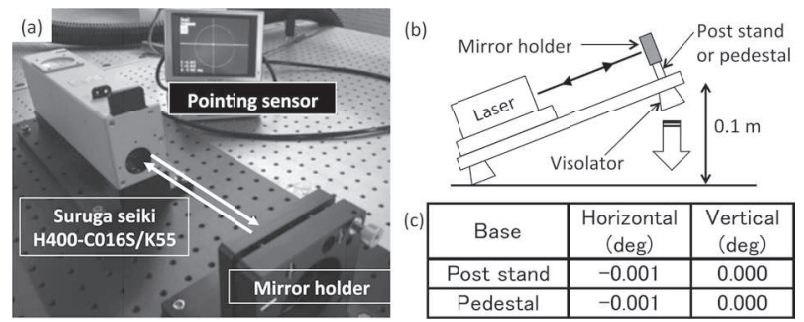

Fig. 4 (a), (b) Setup of the impact resistance test for mirror mount fixing method on a breadboard. (c) Test results for two kinds of fixing methods.
学部品のホルダーへの固定方法や各固定ネジのトルクに 対する定量評価には至っていない. 今後は, 定量評価手 法の確立と，更に大きな衝撃力に対する固定手法の開発 なども検討する予定である。

\section{3 振動励起レーザーの光学配置}

今回開発した高速動作が可能な振動励起レーザーの光 学配置をFig. 5 に示す。本レーザーには，コンクリート を振動させるための高いエネルギー，高速検査のため の50-100 Hz程度の繰り返し数に加え, 温度 ・湿度等の 環境変化に対する耐性や，システムの社会実装を踏まえ 小型化及び低コスト化も望まれる。そこで低コストかつ 環境变化に起因する励起エネルギーや励起波長の変動が 少ないフラッシュランプ励起方式のNd:YAGレーザー （波長1064 nm) を採用した。レーザー発振器として市販 のレーザーヘッドが小型かつ高出力のNd:YAGレーザー (Litron lasers製：TRL-HR 250-100，250 mJ，10 ns）を使 用することで, 増幅器のパス数を減らすと共に, 2つの レーザー増幅媒質を同じ仕様 (14 $\mathrm{mm} \phi, 1.3 \mathrm{at} \%)$ とする ことで，各増幅過程における熱的な影響が等しくなるよ うにした。

一般的に高出力高繰り返しレーザーでは，フラッシュ ランプの高速動作に伴う熱によりレーザーロッドの半径 方向に熱分布(屈折率分布)が生じ，ロッドを通過した光 が屈折し集光もしくは発散してしまう熱レンズ効果や, 熱複屈折効果による入射光の偏光の解消が問題となる. 特に熱レンズ効果が顕著になると，レーザーの集光性能 が低下しコンクリートの加振が困難となるだけではな く, レーザー各部への光学損傷の原因となる. $\mathrm{Nd}: \mathrm{YAG}$ ロッドで生じる熱レンズ効果は，凸レンズによる集光に 近い挙動を示すため, 本レーザーでは各部にレーザー光 の直径と広がり角を補正するレンズ対 (Fig. 5 中のImage tube) を導入した。このレンズ対は，発振器からの良好 なパターンをレーザー内部の各位置(Fig. 5 中の星印)に 転送する像転送光学系としても機能するため, 熱レンズ 効果の低減に加えて，波面の保持及び光軸ずれに対する ビーム位置安定性の向上にも寄与する.

ロッド内で生じる熱複屈折効果については, 増幅器1で 増幅後に偏光を $90^{\circ}$ 回転させ, 増幅器 1 と同じ熱負荷に設 計した増幅器2で再び増幅することにより補償することが 可能である，増幅されたレーザー光は， Image tube 6によ

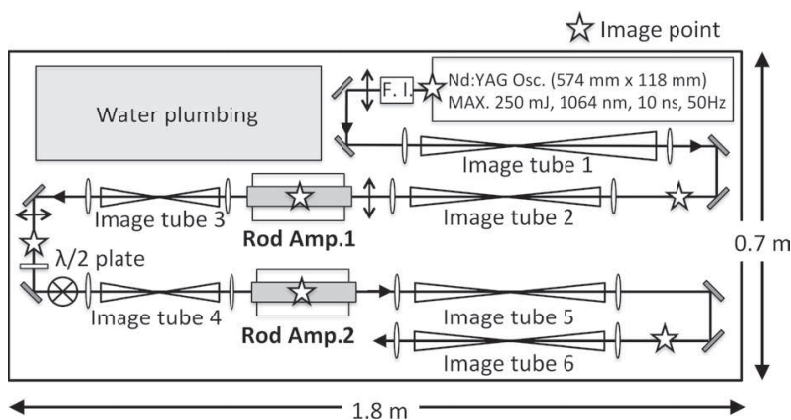

Fig. 5 Optical layout of flash lamp pump Nd:YAG laser for using the hammering laser of the LHT. 
り集光用レンズまで像転送され，数 $\mathrm{m}$ 先のコンクリー 卜上に集光される。像転送光学系の設計を最適化するこ とにより，前述の車両の荷台に搭載可能な $1.8 \mathrm{~m} \times 0.7 \mathrm{~m}$ の定盤上に全ての光学部品を配置することを可能とし た。

\section{4 振動励起レーザー $(50 \mathrm{~Hz})$ の性能評価}

レーザーロッド増幅器は, ロッド1本当り2本のフラッ シュランプで励起しており， ランプリフレクターは2つ の楕円を焦点位置で結合した形状に加工している，楕円 の結合位置 (2つの楕円の共通の焦点)にレーザーロッド を, 反対の焦点位置にフラッシュランプを配置すること で2つのフラッシュランプの光を1本のレーザーロッドに 集約している。フラッシュランプへの最大電気入力エネ ルギーは50 J/本であり，ランプの時間パルス幅は $\mathrm{Nd}: \mathrm{YAG}$ 蛍光寿命が200 $\mu \mathrm{s}$ 程度であることを考慮し て180 s とした. Fig. 6 に発振器の出力を調整して取得 したレーザーロッド増幅器の入出力特性を示す。1段目 のレーザーロッド増幅器(Fig. 6 中の白抜きプロット)で は, $230 \mathrm{~mJ}$ の力エネルギーに対し, $970 \mathrm{~mJ}$ の出力エネ ルギーが得られ，2段目のレーザーロッド増幅器 (Fig. 6 中の黑塗りプロット)では, $220 \mathrm{~mJ}$ の入カネル ギーに対し，2210 mJの出力エネルギーが得られた。

Fig. 6 中の破線及び実線はFrantz-Nodvik式 ${ }^{12}$ から算出し た入出力特性であり，得られた測定結果とほぼ一致して いる。 なお， $50 \mathrm{~Hz}$ 動作時における振動励起レーザーの 増幅器内で発生する熱レンズ効果は焦点距離約 $+2.2 \mathrm{~m}$ と 計測されており，各レーザーロッド直前のImage tubeを 調整することで増幅後のビームが平行光線となるように している.

Fig. 7 (a) に増幅器1への入射ビームパターン，（b)に増 幅器2直後の増幅後ビームパターンを示す. Image tubeに よる像転送と熱レンズ効果の補正により，50 Hz動作に おいても良好なビームパターンが得られている。増幅後

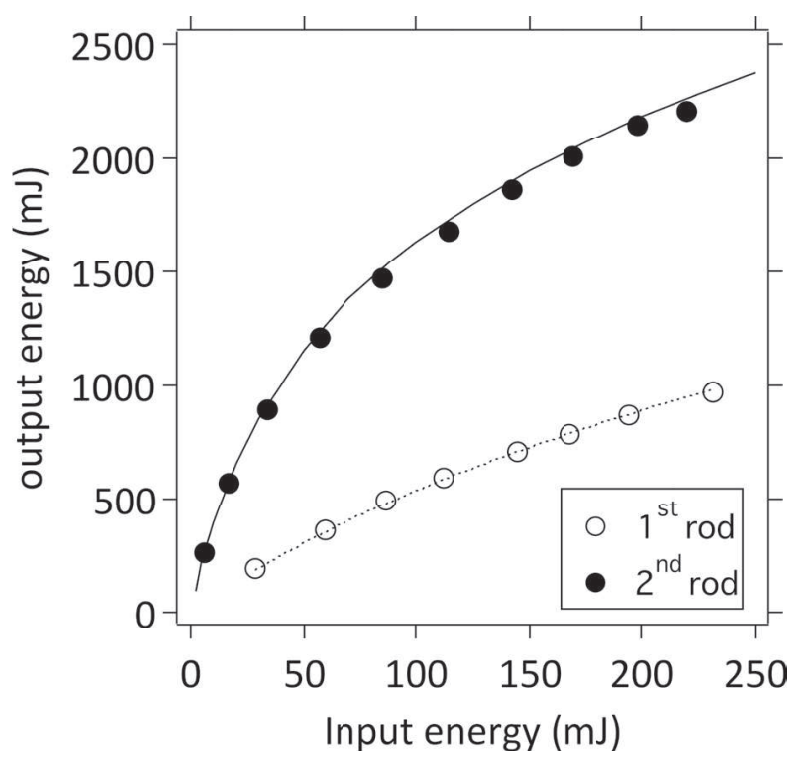

Fig. 6 Characteristics of the amplification of the Nd:YAG rod amplifiers.
の出力は2.1 J(RMS 1\%)であり, 深さ数 $\mathrm{cm}$ の欠陥を検 出するのに十分な出力が得られた。 増幅されたレーザー 光は, 焦点距離の調整が可能な組み合わせレンズを用い てコンクリート上に集光される。実際のトンネル内壁の 形状は真円ではなく楕円であるため，レーザー打音装置 からトンネル内壁までの距離に合わせて集光距離を調整 する必要がある. Fig. 7(c) に焦点距離 $-100 \mathrm{~mm}$, +229 mmの組み合わせレンズを用いて7 m遠方(典型的な トンネルの頂上付近までの距離に相当)に集光したビー ムパターンを示す. $7 \mathrm{~mm} \times 10 \mathrm{~mm}$ の領域にレーザー出力 の $90 \%$ 以上が集約されており，良好な結果が得られた。

\section{5 屋外での動作試験}

Fig. 8 に量子科学技術研究開発機構関西光科学研究所 内の屋外試験場 (a) 及びその中に設置したレーザー打音 装置 (b)の写真を示す。平成28年11月上旬から 12 月中旬 の約 1.5 ケ月間の試験期間における屋外試験場内の温度 及び湿度はそれぞれ6-35ㄷ，20\%-95\%であった。振動 励起レーザーはFig. 3 にも示した様にレーザー打音装置 の上部の防振定盤上に設置されており，下部先端のス キャナー部へ供給され，コンクリート上に導かれる。実 験室から試験場までの移動(フォークリフト等を使用)に よるレーザー出力への影響は観測されておらず，短距離 移動ではあるが，本レーザーが実験室内から建屋外への 移動による衝撃等に対して十分な耐性を有することが示 された。なお，本試験時のレーザーへの電力供給は建屋 からの商用電源で実施した. Fig. 9 に1ヶ月間に渡るレー ザー出力の推移を示す。試験期間内において光軸の調整 を行わない条件下では, 約 $2.1 \mathrm{~J} か ら 1.8 \mathrm{~J}$ まで徐々に出力 が低下していく様子が観測されたが，試験終了後に実験 室内へ戻してから, 増幅器への光軸を微調整することで レーザー出力は1.9 J(Fig. 9 中の点線)まで回復した。試験 の前後において発振器の出力に変動が見られなかったこ とから, アライメントによる出力回復分 $(0.1 \mathrm{~J}$ 分) は, 試 験期間中の光軸ずれに起因すると考えられる。 $0.2 \mathrm{~J} の$ 低
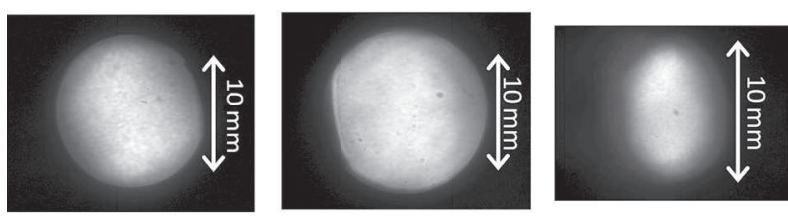

Fig. 7 Beam patterns(a), (b) and focal pattern (c).

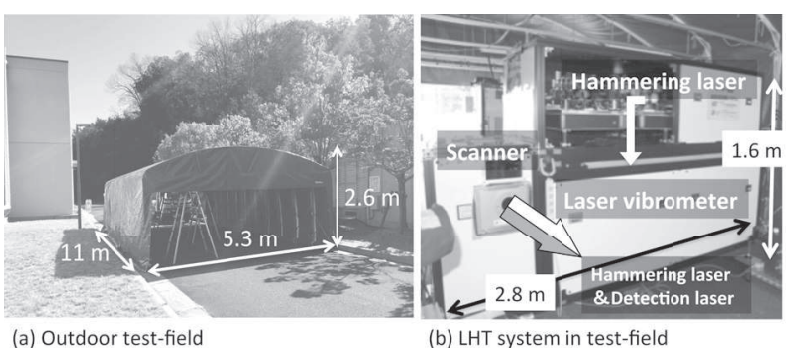

Fig. 8 (a) Outdoor test-field at QST. (b) LHT system in the test-field. 


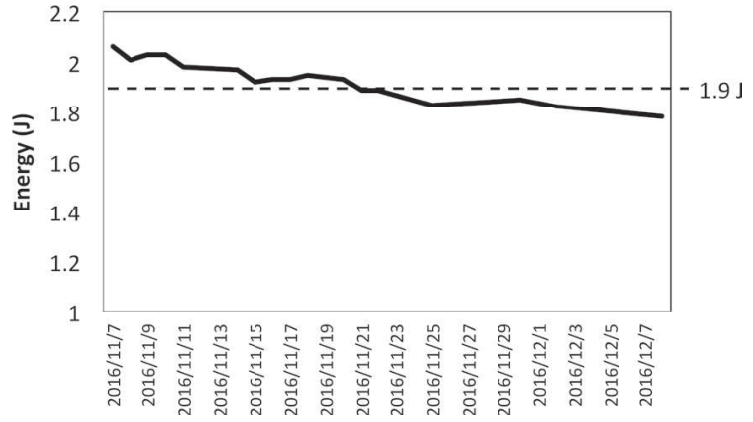

Fig. 9 Energy stability of the hammering laser over one month.

下分については, 増幅器フラッシュランプの劣化が一因 として考えられるが, 試験期間中のフラッシュランプ shot数は, 典型的なランプ寿命よりも少ないため, 光学 素子の表面污柱等その他の要因も今後考慮する必要があ る. 現在は光学素子の洗浄等のメンテナンスに加え, 光 学素子ホルダーの選定も含めた再構築を行っており, 長 期間の運用時の出力安定性の向上に向けた開発を継続し ている.

試験期間中に㧍ける振動励起レーザーの出力低下 (約0.3 J)は, 約 $7 \mathrm{~m}$ 先に設置したコンクリート供試体内 部の欠陥検出の結果には影響して抒らず，約1.5ケ月間 実質メンテナンスフリーにて運用可能であることを示せ たことは，装置の社会実装に向けて大きな意義がある。

\section{6 ディーゼル発動機を用いた動作試験}

3.5 節の屋外動作試験では, 電力を建屋の商用電源か ら供給していたが，実際のトンネル検査では自立稼働が 求められる。屋外での電力供給源としては一般的に ディーゼル発動機が用いられるが, レーザー打音検查で はコンクリートの微小振動を計測するため, 発動機由来 の騒音と振動が計測に悪影響を与える可能性がある。 そ こで，振動励起レーザーのディーゼル発動機を用いた動 作試験と合わせて, レーザー振動計測システム (Fig. 8 (b)の下側)の設置されている定盤の振動を計測した，発 動機はデンヨー製DCA-45ESI (45 kVA) を使用し, 騒音 レベルはレーザー打音装置周辺で約80 dB (サトテック製 SD-23SDにて計測)であった. Fig. 10 に発動機からの電 力供給時の振動励起レーザーの出力安定性を示す. 20 分 間の計測に扔いて出力は1\%(RMS)の精度で安定してい る. 発動機の動作由来の出力低下が 900 秒のところで見 られたが, その後も問題無く動作している。振動励起 レーザーの消費電力は約 $20 \mathrm{kVA} ゙$ あり，25 kVAクラス の発動機1台でもレーザー打音装置全体の稼働が可能で ある. Fig. 11 に, 発動機稼動状態に扔けるレーザー振 動計測システムの定盤の振動計測結果を示す。点線は筐 体の蓋を開けている状態，実線は閉じている状態をそれ ぞれ示す，定盤に対して垂直方向の振動では蓋の有無に 関わらず特異な振動は観測されておらず，筐体の防振機 構が十分に機能していることが分かる，水平方向に関し

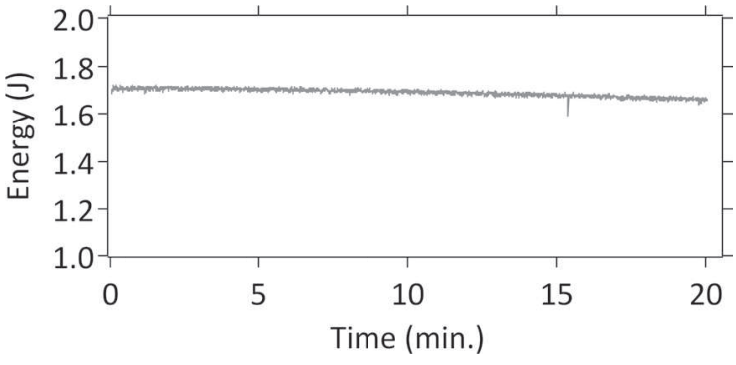

Fig. 10 Energy stability of the hammering laser under the use of the diesel electric generator.
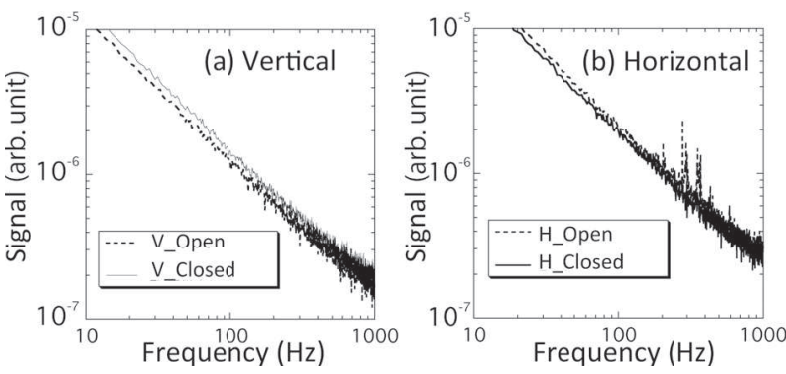

Fig. 11 Vibration of the breadboard of the laser vibrometer in the LHT system under the use of the diesel electric generator.

ては蓋を開けた状態では200-400 Hz帯において共振が観 測されているが，遮音材付きの蓋により共振が解消され ることが観測された。レーザー打音装置に組み込んだ防 振・防音機構により, 発動機による振動の影響を排除で きたことから，レーザー打音装置の屋外での自立稼働が 可能であることが示された。

今後更に小型化・省電力化を進めるためには, 半導体 レーザー(LD) 励起の導入が有効であると考えられる。

しかしながら今回使用したNd:YAGでは蛍光寿命が比較 的短く，かつ効率的な励起が可能な波長带域が狭いた め, 高ピーク出力のLD及び温度 (波長) 安定性の高いLD が必要であり、レーザー媒質の再選定も含めた検討が重 要な課題の一つである。

\section{4. まとめ}

今回我々は，レーザー打音検査の高速化に必要な振動 励起レーザーの開発を行い，簡便な構造を有するフラッ シュランプ励起Nd:YAGレーザーにより，小型 $(1.8 \mathrm{~m} \times$ $0.7 \mathrm{~m})$ かつ繰り返し $50 \mathrm{~Hz}$ ，出力 $2 \mathrm{~J}$ 得ることに成功し た。また，本レーザーは実験室内だけでなく，屋外試験 場での1.5 ケ月間の運用試験に抢いてメンテナンスフ リーでの稼働に成功し，かつディーゼル発動機による自 立稼動が可能であることを示した，更に平成28年11月に レーザー技術総合研究所, 理化学研究所, 日本原子力研 究開発機構と共同で，本レーザーを用いたレーザー打音 検查の屋外試験を行い，内部に模擬的な欠陥を有するコ ンクリート供試体を対象として50 Hzでの高速欠陥検査 に成功している゙、今後はより深い欠陥を検知するため

${ }^{\dagger}$ http://www.qst.go.jp/topics/itemid034-001306.html 
の更なる高出力化及び移動車両への搭載化を進める計画 である。

\section{謝 辞}

本装置の開発に対し, 様々なご助言を頂きました(公 財) レーザー技術総合研究所の島田 義則様, 倉橋 慎理 様, 北村俊幸様に感謝いたします。本研究の一部は, 内閣府総合科学技術・イノベーション会議の「SIPインフ ラ維持管理・更新・マネジメント技術」(管理法人: JST) によって実施されました。

\section{参考文献}

1）国土交通省：道路統計年報 2015 .
2）国土交通省：鉄道統計年報 2013 .

3）島田 義則：検査技術 11 (2006) 8 .

4）篠田 昌弘, 大村 寛和, 御崎 哲一, 島田 義則, 内田成明： RTRI REPORT, 23 Dec. (2009) 29.

5）倉橋 慎理，オレグコチャエフ，島田 義則，乗松 孝好： レーザー研究 11 (2014) 849.

6) 御崎 哲一：京都大学社会基盤工学博士論文 (2015).

7) 長谷川登：化学 71(2016) 72.

8）長谷川 登，錦野 将元，三上 勝大，岡田大，近藤 修司， 河内 哲哉, 島田 義則，倉橋 慎理，北村 俊幸：検査技術 22 (2017) 57.

9）島田 義則, 倉橋 慎理, オレグ コチャエフ, 倉橋 慎理, 北村 俊幸：レーザー研究 45 (2017) 423 .

10) T. Hatae, T. Hayashi, E. Yatsuka, S. Kajita, H. Yoshida, H. Fujita, M. Nakatsuka, K. Yahagi, K. Shinobu, T. Ono, et al.: J. Plasma Fusion Res. Ser. 9 (2010) 253.

11) A. Bayramian, J. J. Armstrong, G. Beer, R. Campbell, B. Chai, R. Cross, A. Erlandson, Y. Fei, B. Freitas, R. Kent, et al.: J. Opt. Soc. Am. B 25 (2008) B57.

12) L. M. Frantz and J. S. Nodvik: J. Appl. Phys. 34 (1963) 2346. 